УДК 911.2:551.3 (477.75+551.4.038)

\title{
СОСТОЯНИЕ БЕРЕГОВ И ЭКЗОГЕННЫЕ ГЕОЛОГИЧЕСКИЕ ПРОЦЕССЫ МЕЖДУ МЫСАМИ ВИНОГРАДНЫЙ И АЙЯ НА ЮГО-ЗАПАДНОМ ПОБЕРЕЖЬЕ КРЫМА *
}

Агаркова-Лях И.В. ${ }^{1}$, Лях А.М. ${ }^{2}$

${ }^{1}$ ФГБНУ «Институт природно-технических систем», г. Севастополь, Российская Федераиия, e-mail:iva_crimea@mail.ru

${ }^{2}$ ФГБУН «Институт морских биологических исследований имени А.О. Ковалевского РАН»,

2. Севастополь, Российская Федерация,

e-mail:me@antonlyakh.ru

Рассмотрена история изучения юго-западной части Крымского побережья между м. Виноградный и м. Айя в границах города Севастополя. Описаны условия, определяющие современное состояние берегов, характер и динамику экзогенных геологических процессов: типы берегов и их литологический состав, тектоническое строение и направленность тектонических движений, абсолютные высоты. Охарактеризованы морфометрические показатели формирующихся здесь пляжей, их генезис, гранулометрический и вещественный состав. Дана оценка активности развития и распространения по территории оползней, обвалов, осыпей, камнепадов, абразии, денудации, селей, эрозии и карста. На основе доступных данных обобщены количественные и качественные характеристики наиболее значимых экзогенных геологических событий на побережье за период с начала 80 -х гг. прошлого века по настоящее время. Предложены мероприятия для контроля динамики опасных экзогенных процессов и повышения безопасности в прибрежной зоне.

Ключевые слова: пляжи; оползни; обвалы; камнепады; абразия; мониторинг берегов.

\section{Введение}

В последние десятилетия растет интенсивность освоения труднодоступных участков крымского Южнобережья, сопровождаемая увеличением антропогенной нагрузки на его приморскую часть. Активизация хозяйственной деятельности на побережье стимулирует интенсивность и частоту проявления опасных и неблагоприятных экзогенных геологических процессов. В этой связи становится актуальной региональная оценка современного состояния берегов и динамики неблагоприятных и опасных экзогенных геологических процессов.

Цель статьи - обобщить фондовые и литературные данные о состоянии берегов и динамике экзогенных геологических процессов между м. Виноградный и м. Айя в юго-западной части побережья Крыма и дополнить их актуальными материалами собственных полевых исследований.

\section{Материалы и методы}

Исходными материалами послужили: опубликованные работы; фонды Института минеральных ресурсов, Крымской гидрогеологической экспедиции (КГГЭ) и Государственного геологического предприятия (ГГП) «Крымгеология»; картографические источники; интернет-ресурс Гугл Планета Земля; результаты маршрутно-полевых исследований авторов в период с 2012 по 2018 гг. Для изучения литологического состава берегов, оценки морфометрических характеристик берегов и пляжей, а также расчета динамики последних применялись методы наблюдения,

* Работа выполнена в рамках гос. заданий ФГБНУ ИПТС (№ 0012-2019-0007) и ФГБУН ИМБИ (гос. регистраиионный № AАAА-A18-118020890074-2). 
инструментальных и полуинструментальных измерений, сравнительно-географический и фотометод.

\section{Результаты и обсуждение}

Первые работы по краткой характеристике и районированию данных берегов относятся к середине XX в. (Зенкович, 1958a, 1958б, 1960). Позже были исследованы пляжи (Романюк, 1968), дана оценка развития экзогенных процессов и их прогноз (Шуйский, 1974, 1979; Прогноз экзогенных..., 1979). В это же время обширные береговые изыскания в Крыму вели Институт минеральных ресурсов, КГГЭ, ГГП «Крымгеология» и др. (Изучение оползней..., 1983; Разработка методических..., 1985; Составить кадастр..., 1988; Изучение условий..., 1993).

В 2000-е гг. появился ряд публикаций, в которых пляжи, экзогенные процессы и современные ландшафты на изучаемых берегах рассматривались в составе всего Крымского п-ова (Шуйський, 2000; Клюкин, 2005; Рудько, Ерыш, 2006; Агаркова-Лях, Скребец, 2007; Долотов, Иванов, 2007; Игнатов, Орлова, Санин, 2014; Современное состояние..., 2015; Игнатов, Лукьянова, Соловьева, 2016 и др.). Их региональные исследования были посвящены геоморфологии берегов, состоянию пляжей, неблагоприятным и опасным экзогенным процессам (Попов, 2006; Агаркова-Лях, 2007; Орлова, 2010; Новиков, Каширина, Белоконь, 2014; Попов, Лисицкая, Поспелова, 2014; Лазицкая, 2014; Луговой, 2016; Горячкин, Федоров, 2018, 2019).

Берега Крымского полуострова развиваются в различных тектонических, литолого-геоморфологических и гидродинамических условиях. По этим признакам между м. Лукулл и м. Сарыч были выделены четыре береговых участка (Агаркова-Лях, 2017). Отличия между ними наиболее ярко выражаются в литологическом составе берегов и их противоабразионной устойчивости, а также связанных с ними характере и интенсивности проявления экзогенных геологических процессов. Берега от м. Лукулл до м. Виноградный были рассмотрены ранее (Агаркова-Лях, 2017; Агаркова-Лях, Лях, 2019). Настоящая статья продолжает серию публикаций по севастопольским берегам.

Согласно морфогенетической классификации, участок между мысами Виноградный и Айя представлен тремя типами берегов: абразионными на юге Гераклейского полуострова (от м. Виноградный до Балаклавской бухты), риасовыми или бухтовыми ингрессионными (Балаклавская бухта) и абразионно-бухтовыми (от Балаклавской бухты до м. Айя) (Зенкович, 1958б; Составить кадастр..., 1988). Так как в настоящее время берега Балаклавской бухты, практически, полностью преобразованы хозяйственной деятельностью, отнесем их к антропогенным.

Бо́льшая часть описываемых берегов приурочена к Юго-Западному синклинорию мегантиклинория Горного Крыма (Муратов, 1973). По результатам анализа уровнемерных наблюдений за период 1873-1985 гг., прилегающие к горам берега Черного моря опускались со средней скоростью 2,6 мм/год в районе Севастополя (Клюкин, 2007). Современные вертикальные движения на прибрежном шельфе тоже отрицательные, со скоростью 1,0-2,0 мм/год (Разработка методических..., 1985).

Берега имеют максимальные для региона и всего Крымского полуострова высоты. Их абсолютные отметки достигают более 500,0 м у м. Айя, 300,0 м у м. КаяБаш и 168,0 м у м. Фиолент. Значительная по протяженности часть берегов круто обрывается в море, как на участках у м. Фиолент, Свято-Георгиевского монастыря, высот Кая-Баш, м. Балаклавского (Георгия) и м. Айя.

Берега сложены, главным образом, коренными породами: магматическими и метаморфическими (рис. 1). Основываясь на порядке средней скорости абразионных процессов, протекающих в отложениях разного литологического состава, на исследуемых берегах выделены три категории пород: очень устойчивые, устойчивые и 
средней устойчивости к абразии (Агаркова-Лях, 2006). По этому показателю берега между м. Виноградный и м. Айя отнесены, преимущественно, к категории очень устойчивых и объединены в единый участок. Их отличительной особенностью является высокая прочность, благодаря чему берега почти не абрадируются. Первые выходы изверженных вулканических пород - кварцевых кератофиров начинаются у м. Виноградный и представлены мысами (Виноградный, Броневой, Лермонтова, Сфинкс (Львенок), Фиолент и др.), скалами-островками (Орест, Пилад, Святого Явления (Георгиевская) и др.) и береговыми скалами (Крестовая (Монах) и др.) (рис. 2). В двух километрах к востоку от м. Фиолент вулканические породы исчезают, а береговой обрыв прорезает Мраморная балка, проходящая по линии тектонического сброса, отделяющего слоистые сарматские известняки от массивных верхнеюрских мраморизованных. Последние тянутся с некоторыми перерывами почти до м. Айя, моделируя форму берегов. От урочища Аязьма до м. Айя на берегу развиты глыбовые навалы известняков, исчезающие на обрывистых участках.

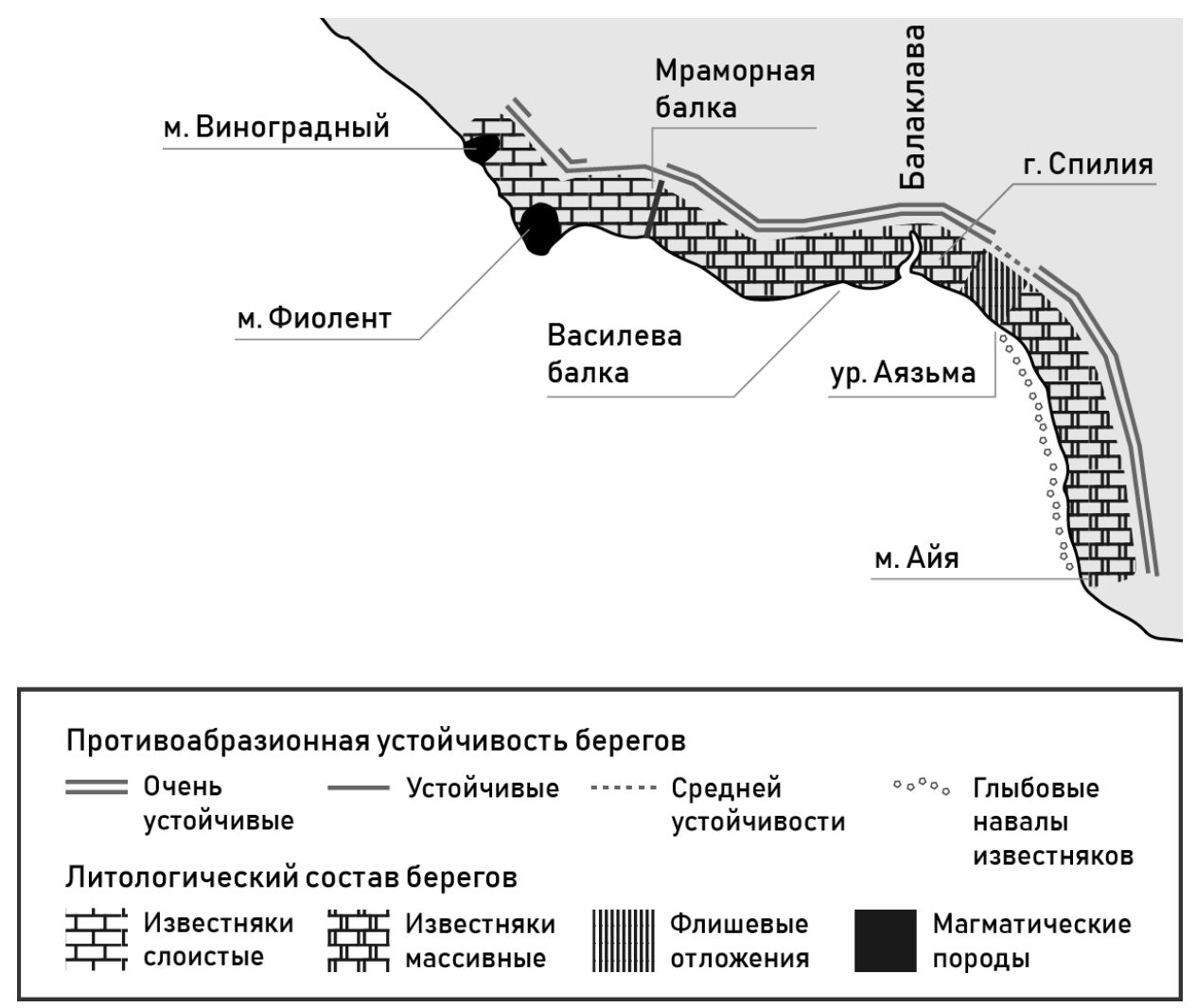

Рис. 1. Литологический состав и противоабразионная устойчивость берегов

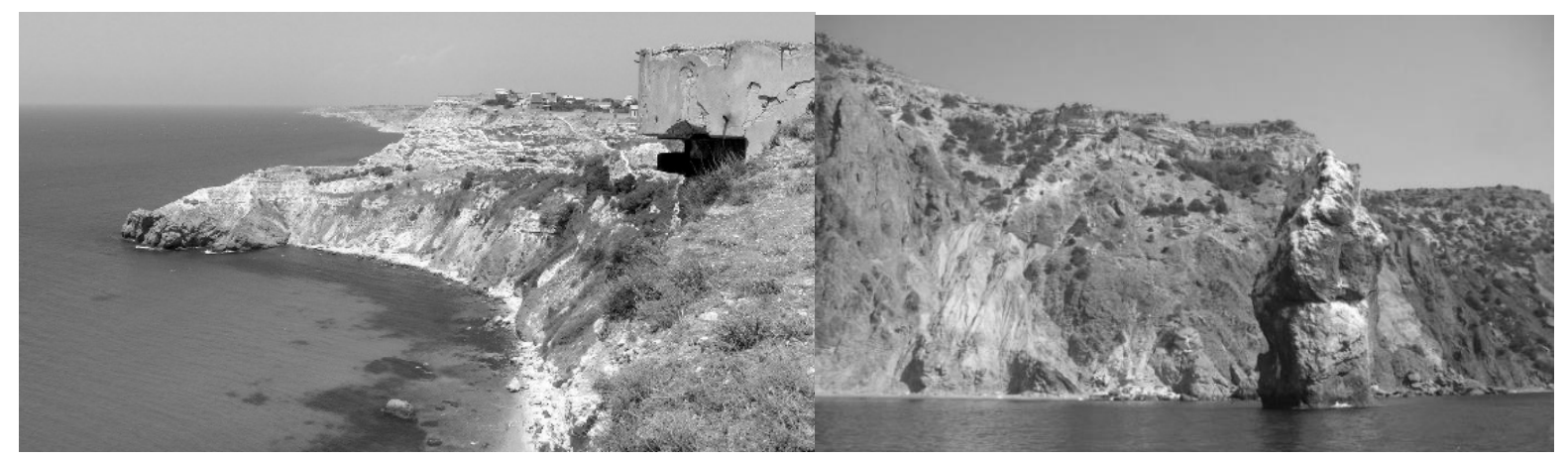

Рис. 2. Вид с юга на «разлапистый» м. Виноградный из магматических пород (слева). Скала Пилад у м. Фиолент (справа) (Фото из сети интернет и авторов) 
На участке от м. Балаклавский до урочища Аязьма в строении берегов участвуют флишевые отложения (верхний триас - нижняя юра). Их основу образуют породы таврической глинисто-сланцевой свиты, представленной чередованием глин, аргиллитов, алевролитов и песчаников. Они отнесены к породам средней устойчивости к абразии (рис. 1).

У м. Фиолент встречаются отдельно стоящие в море скалы (Орест, Пилад и пр.) призматической островерхой формы высотой до 30,0 м (Попов, Лисицкая, Поспелова, 2014), которые являются результатом селективной абразии берегов. Они располагаются в 25,0-40,0 м от берега и называются кекуры (рис. 2, справа). Скалы у берегов урочища Аязьма (Первый и Второй Шпитали (Паруса или Зубы)), по-видимому, имеют обвально-оползневое происхождение (рис. 3).

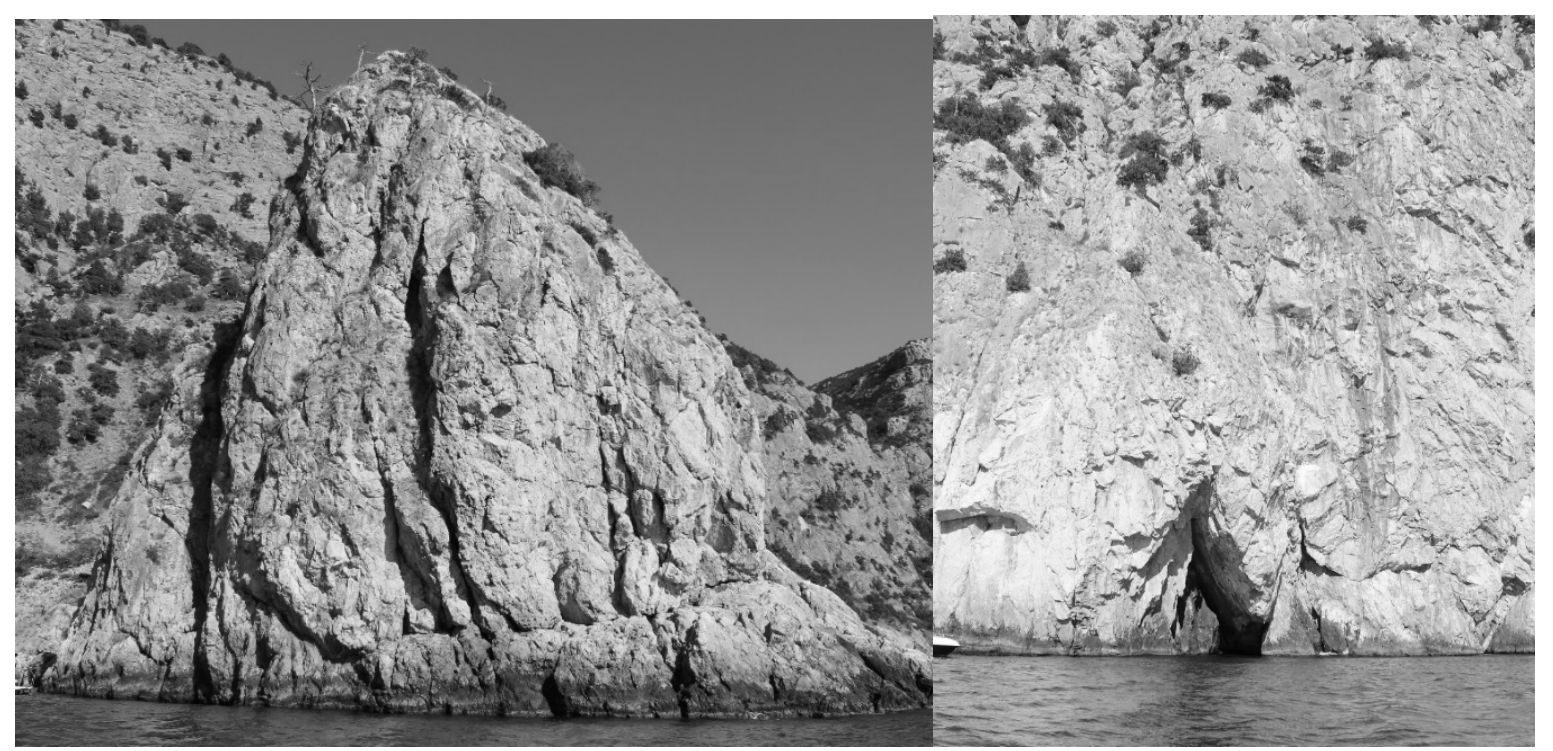

Рис. 3. Скала Второй Шпиталь близ м. Айя (слева). Вход в грот под м. Айя (справа) (Фото авторов)

Аккумулятивные формы на описываемых берегах повсюду имеют абразионное питание (Романюк, 1968) и ограниченное развитие, поскольку их разрушение дает чрезвычайно мало обломочного материала. Узкие карманные пляжи средней шириной 5,0-10,0 м образуются в вогнутостях контура береговой линии. Ширина пляжей характеризуется внутригодовой сезонной динамикой: ростом в теплый период года и сокращением, вплоть до полного размыва - в холодный.

Между м. Виноградный и Балаклавской бухтой формируются 7 пляжей: Броневой, Царский, Каравелла, Патриот, Адмиральский (Командирский), Яшмовый и Васили. Наибольшими являются два последних. Яшмовый пляж песчано-галечного гранулометрического состава средней шириной 20,0 м и длиной около 1,5 км (Попов, Лисицкая, Поспелова, 2014). Пляж Васили имеет антропогенное происхождение. Он сформировался в устье Василевой балки из материала отвалов Псилерахского карьера. Его образование началось около 30-35 лет назад. Сейчас его протяженность равна 200,0 м, средняя ширина 18,0-20,0 м (максимально - до 50,0 м). Он также песчаногалечного состава с участками валунно-глыбового навала. Полевые исследования авторов и анализ фотоматериалов позволили рассчитать среднюю скорость роста пляжа за период с 2006 по 2016 г., составившую 1,6-2,5 м/год. Пейзажно-ландшафтная и рекреационная привлекательность пляжа Васили нивелируется соседством Псилерахского карьера, чьи отвалы являются источником многолетнего оползнеобразования в балку со смещением обломочного материала к урезу воды. 
Кроме того, авторами настоящей работы обнаружена трещина в скальном блоке над западной частью пляжа, а по данным (Геолог предсказал..., 2018) над его восточной частью растет трещина между склоном и блоком известняка. Таким образом, посещение пляжа Васили опасно из-за потенциальной угрозы развития обвалов, камнепадов и оползней.

Между Балаклавской бухтой и м. Айя расположены 8 пляжей: Серебряный (Ближний или Микро-Яло), Золотой (Дальний или Мегало-Яло), Кабельный, Блуждающий, Инжир, Командирский, Дальний Инжир, Белый. Их общая протяженность составляет менее 2,0 км, максимальная ширина - 20,0 м. Самые протяженные из них - гравийно-галечный пляж Серебряный длиной 400,0 м и галечновалунный пляж Золотой длиной 800,0 м. В вещественном составе отмеченных гравийно-галечных пляжей преобладают известняк или сланцы таврической свиты, далее следуют кварц и кремень. На некоторых пляжах присутствует мергель и конгломераты, а также изверженные породы (Составить кадастр..,, 1988). Вклад биогенного материала в отложения пляжей повсюду очень незначителен. Пестрый минералогический состав отмечен южнее м. Фиолент, на Яшмовом пляже, где встречается разноцветная яшма, сердолик, халцедон, агат.

Экзогенные геологические процессы. На исследуемых берегах развиты такие опасные экзогенные геологические процессы, как оползни, обвалы, осыпи, камнепады и сели, и неблагоприятные, как абразия, денудация, карст и эрозия. Доминирующими экзогенными процессами на берегах из прочных пород являются денудация, оползни, обвалы, осыпи, камнепады и карст. На флишевых берегах развиты абразия, оползни, обвалы, осыпи, камнепады, денудация, эрозия и сели. Согласно типам экзогенных процессов, Ю.Д. Шуйский (2000) выделил между мысами Фиолент и Айя абразионноденудационные и абразионно-обвальные клифы. Ниже подробнее рассмотрим характер развития и приуроченность экзогенных геологических процессов.

Денудация. Обращенные к морю массивы скал активно подвергаются денудации (физическое выветривание и др.), что связано, главным образом, с суточным и годовым режимом их нагрева-охлаждения, и увлажнения. В частности, среднемноголетние скорости выветривания флишей составляют от 0,001 до $0,1 \mathrm{~m}^{3} / \mathrm{m}^{2}$ (Разработка методических..., 1985).

Оползни. По состоянию на 1 января 2019 г. между мысами Виноградный и Айя зафиксировано около 50 оползней (Ежегодный доклад..., 2019). Формирующиеся здесь оползни имеют естественное, антропогенное (техногенное) и смешанное естественноантропогенное (естественно-техногенное) происхождение. Естественные оползни активизируются абразионными, гравитационными и эрозионными процессами, атмосферными осадками. Наиболее частыми причинами возникновения естественнотехногенных оползней является нарушение противооползневого режима, сопровождаемого «подрезкой» склонов или их «пригрузкой» обломочным материалом и строительным мусором в результате террасирования склонов, строительства и пр.; самовольным бурением скважин, нерегулируемым поливом и несанкционированным складированием твердых бытовых отходов. Усилению гравитационных процессов также способствуют антропогенные пожары, уничтожающие древесно-кустарниковую и травяную растительность склонов, что в значительной мере стимулирует активизацию существующих и образование новых оползней (Горячкин, Федоров, 2019).

Значительную роль в формировании оползней играет абразия. Оползневые участки абразионного происхождения расположены у мысов Виноградный, Лермонтова, Фиолент. Высокая подвижность оползня абразионного типа (№31) отмечена у м. Фиолент. Его последняя активизация произошла 30 ноября 2016 г. (Ежегодный доклад..., 2017). Высота берегового обрыва в месте отрыва оползня составила 40,0-50,0 м; общая площадь - около $250,0 \mathrm{~m}^{2}$. Вместе с участком берега 
обвалилась часть идущей вдоль его кромки асфальтированной дороги (На мысе..., 2016). К оползневой зоне примыкает база отдыха «Каравелла», где отмечены многочисленные следы активности оползня: трещины в строениях и грунте, просадки грунта и др. (Ежегодный доклад..., 2017).

Среди тридцати четырех оползней, обнаруженных между Мраморной балкой и м. Айя, более половины (22 единицы) имеют естественный генезис, третья часть (11 единиц) - естественно-техногенный и один - техногенный (Горячкин, Федоров, 2019). К последней группе отнесен крупнейший по своей мощности техногенный оползень в Василевой балке (№2), сошедший от южного борта Псилерахского карьера флюсовых известняков. Объем тела оползня составляет около 500,0 тыс. м $^{3}$; он сложен разнородными грунтами отвалов (Ежегодный доклад..., 2017). Подвижки материала отвалов здесь отмечались регулярно, но крупнейшая из них за последние годы произошла в декабре 2006 г., когда 6,0 тыс. м грунтов перекрыли западную часть пляжа Васили, выдвинувшись в море на 50,0-100,0 м при ширине языка оползня в 100,0-200,0 м (Илларионов, 2006; Горячкин, Федоров, 2019). В настоящее время длина оползня оценивается в 970,0 м, ширина - 250,0 м, площадь - 24,25 га (Ежегодный доклад..., 2016). Близость оползня к действующему карьеру, где перемещается тяжелая техника, проводятся взрывные работы и образуются отвалы создает условия для высокой вероятности его внезапной активизации.

Более трети оползней между Мраморной балкой и м. Айя имеют абразионное происхождение (Горячкин, Федоров, 2019). В границах урочища Мегало-Яло выявлены три абразионных оползня; в урочище Аязьма - два. Из них активным в последние годы был единственный оползень у пляжа Золотой. В урочище Вангели на протяжении 0,6 км на узком (от 75,0 до 150,0 м) глыбовом склоне находятся шесть небольших естественных оползней: три абразионных и три «висячих» (Горячкин, Федоров, 2019).

Обвалы, осыпи и камнепады. У м. Фиолент, под плато Кая-Баш и Караньским, от урочища Аязьма до м. Айя широко развиты обвально-осыпные процессы и камнепады (рис. 4). Так, у бровки Караньского плато, рассеченного во всех направлениях тектоническими нарушениями, образуются крупные обвалоопасные блоки. Объемы их разовых обрушений достигают 20,0-80,0 м³ (Опасные обрушения..., 2013).

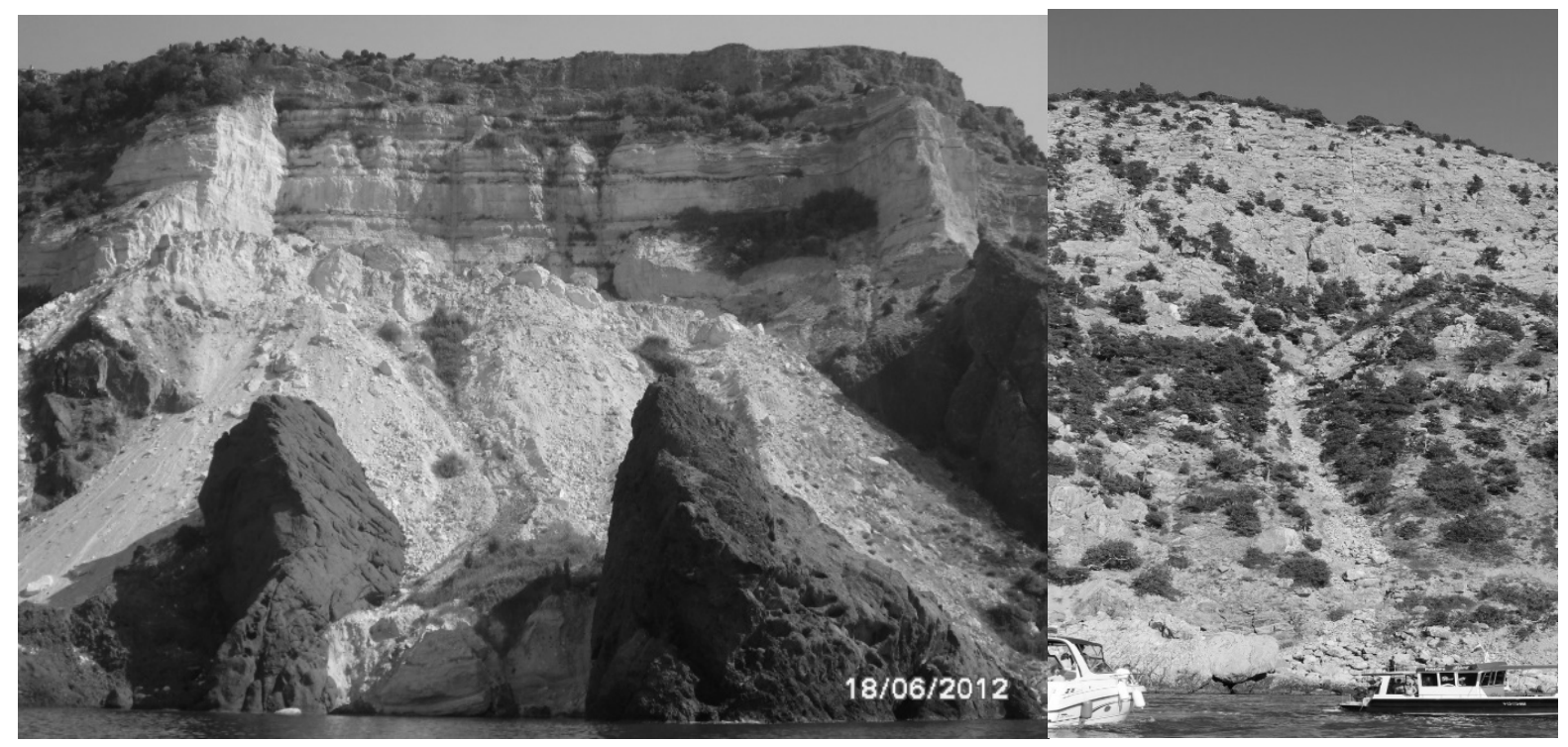

Рис. 4. «Висячие» осыпи под обрывами в районе м. Фиолент (слева) и у м. Айя (справа) (Фото авторов) 
В 1982 г. в ландшафтном заказнике «Мыс Айя» был зафиксирован обвал массивных известняков объемом около 2,0 тыс. м³ (Корженевский, Борисенко, Корженевский и др., 1989). В июне 1997 г. произошел самый крупный во всем Горном Крыму за последние несколько десятков лет обвал, когда почти с вершины горы КокияКая в южную часть урочища «Затерянный мир» у м. Айя упал блок верхнеюрского известняка объемом около 90,0 тыс. м². В результате сложного движения по склону произошел переход одного процесса (обвала) в другой (оползень) с вовлечением подстилающих флишоидных пород. При этом был уничтожен реликтовый лес на площади 3,0 га (Горячкин, Федоров, 2019). Более 200,0 тыс. т скальной массы выдвинули зону пляжа на 50,0 м, а в языке оползня в море выдавило на поверхность глыбы, обросшие бурыми водорослями. В конце 1999 г. у пос. Фиолент в районе базы отдыха «Каравелла» произошел скальный обвал объемом 40,0 тыс. м ${ }^{3}$ и массой 80,0 тыс. т. Тогда же неподалеку случился второй обвал объемом 10,0 тыс. м ${ }^{3}$ и массой 20,0 тыс. т. (Клюкин, 2005). В 2003 г. обвал объемом около 300,0 м³ в южной части урочища Аязьма прорубил в соснах просеку до уреза моря (Горячкин, Федоров, 2019). В июне 2005 г. обвал у базы отдыха «Каравелла» уничтожил ведущую к морю лестницу и часть пляжа (На мысе..., 2005). В августе 2018 г. с горы Спилия у Балаклавы на тропу скатился блок, рассыпался на части и уничтожил деревья на пути своего движения ниже тропы (Геолог предсказал..., 2018).

Скопление рыхлого обломочного материала на береговых склонах приводит к формированию висячих осыпей (рис. 4). Они образуются при участии процессов денудации и деятельности человека. Перемещение висячих осыпей под действием гравитационных сил вниз представляет угрозу для находящихся на узких пляжах отдыхающих, под обрывами в море - каякеров, аквалангистов и лодочников. Атмосферные осадки способны превращать висячие осыпи в водокаменные сели.

Камнепады происходят при падении обломков, отделившихся от скальных массивов или в результате размыва рыхлых грунтов, лежащих в их основании.

К сожалению, обвально-осыпные процессы и камнепады способны травмировать людей в прибрежной зоне. В этом отношении печальной статистикой отличаются окрестности м. Фиолент и м. Айя. Так, в 2002 г. из-за камнепада у базы отдыха «Каравелла» пострадали четыре человека (Клюкин, 2005; За последние..., 2017). В июле 2003 г. у м. Айя обрушились 2,0 тыс. м³ пород, потопившие два катера; тогда же фрагмент камня задел аквалангиста, находящегося на глубине 16,0 м. В августе 2004 г. у гротов м. Айя обвалом был отправлен на дно 20-метровый прогулочный катер и серьезно травмирована женщина (Сейсмику Крыма..., 2016; Обвал скалы..., 2004). В результате камнепада в августе 2012 г. на м. Фиолент погиб юноша (Клюкин, 2005; За последние..., 2017).

Абразия. Скорости абразии прочных пород повсюду ничтожны и близки к нулю, поэтому эти берега почти не изменены морем. Почти не поддаются абразии берега м. Фиолент и западнее него, высоты Кая-Баш, окрестности Балаклавы, м. Айя и глыбовые навалы известняков (Зенкович, 1958; Составить кадастр..., 1988; Изучение оползней..., 1983; Попов, Лисицкая, Поспелова, 2014). Согласно (Штенгелов, 1970), за последние 2000 лет средняя скорость разрушения Южного берега Крыма составила 0,001-0,002 м/год. Ю.Д. Шуйский отмечает, что сложенные изверженными кристаллическими породами мысы Южнобережья разрушаются со скоростью менее 0,001-0,005 м/год (Шуйский, 1986; Шуйський, 2000). При этом, наблюдаются отличия скоростей абразии в породах разного типа. Так, в работе (Попов, Лисицкая, Поспелова, 2014) отмечается, что магматические породы у м. Фиолент отступают быстрее, чем мраморизованные известняки из-за наличия менее прочных включений и меньшей монолитности. 
На сложенных флишами берегах абразия изменяется от 0 до 0,01-0,05-0,07-0,12 м/год (Рудько, Ерыш, 2006; Изучение оползней..., 1983; Разработка методических..., 1985). Наиболее активно отступают клифы между пляжами Серебряный и Золотой (Попов, Лисицкая, Поспелова, 2014). По данным (Горячкин, Федоров, 2019) интенсивность абразии в пределах Микро- и Мегало-Яло составляет от 0,1 до 0,3 м/год, что подтверждает наблюдаемое нами многолетнее сокращение ширины пляжа Золотой. В делювиальном слое абразия может достигать 0,2-2,5 м/год (Шуйський, 2000).

У уреза воды в зонах трещиноватости известняков на обрывистых и берегах с узким пляжем прибойным потоком выработаны абразионные ниши высотой и глубиной до 1,0-2,0 м, а также гроты шириной и длиной до 10,0 м. Гроты встречаются под массивом Кая-Баш (Котово) и у Василевой бухты (оба - надводные), у м. Балаклавский (полузатопленный) (Попов, Лисицкая, Поспелова, 2014). Абразионные гроты формируются и в вулканических породах. Так, у м. Лермонтова волнами пробит сквозной грот Дианы протяженностью 10,0-15,0 м. Своды его надводной части высотой около 10,0 м; глубина в подводной части - 12,0-14,0 м (Ялта: путеводитель..., 2019). В скале-островке Орест у м. Фиолент имеется сквозной подводный грот протяженностью около 15,0 м, вход в который расположен на глубине 13,0 м (Ялта: путеводитель..., 2019).

Сели. В условиях горного рельефа в периоды интенсивного выпадения осадков на участках развития рыхлых отложений могут формироваться сели, материал которых аккумулируется на берегу и подводном склоне. Так, во время сильных дождей под плато Кая-Баш возможен сход в море водокаменных селей (Опасные обрушения..., 2013). По материалам А.Н. Олиферова (2005), между урочищем Аязьма и м. Айя отмечается средняя степень селевой опасности. Согласно (Горячкин, Федоров, 2019), в пределах урочища Аязьма при значительных осадках происходят селеподобные выносы в пляжную зону. Селеопасный участок расположен в ущелье урочища Кокия у м. Айя, где 5 июля 1980 г. после ливневых дождей был зафиксирован мощный селевой поток. Образовавшийся паводок размыл отложения притальвежных осыпей и обвалов и трансформировался в селевой вал высотой около 4,0 м. Общий объем выноса обломочного материала из дресвы, щебня и глыб в урочище «Затерянный мир» составил 5,0 тыс. м или 9,0 тыс. т (Клюкин, 2005).

Эрозия. Процессы эрозии имеют ограниченное распространение на береговых склонах из флишевых отложений (урочища Микро- и Мегало-Яло) и представлены плоскостной и линейной эрозией поверхностными (преимущественно, атмосферными) водами. Усилению эрозионных процессов способствуют антропогенные пожары, уничтожающие склоновую растительность. Скорости плоскостного смыва флишей составляют от 0,1 до $0,13 \mathrm{~m} /$ год (Разработка методических..., 1985). В результате развития процессов эрозии прибрежные склоны приобретают характерный вид ландшафтов типа «бедленд».

Карст. Согласно районированию, берега расположены в пределах Севастопольского и Байдаро-Балаклавского карстовых районов Предгорно-Крымской и Горно-Крымской карстовых областей соответственно (Вахрушев, 2009). В карбонатных породах развиваются карстово-суффозионные процессы и образуются гроты. Через них происходит субмаринная разгрузка подземных вод.

Полузатопленные и подводные карстово-суффозионные гроты встречаются у м. Айя (рис. 3, справа). Максимальных размеров достигает грот, расположенный в 100,0 м от м. Пелекето наибольшей шириной 8,0 м и длиной 40,0 м (Юровский, Байсарович, Щетинин, Кондратьев, 2000). Дебит субмаринной разгрузки пресных вод через грот составляет 2,0-10,0 тыс. м³/сут (Кондратьев, Прусов, Юровский, 2010).

Особую угрозу экзогенные геологические процессы представляют для растительных сообществ и ландшафтов особо охраняемых природных территорий 
(ООПТ) между мысами Виноградный и Айя: государственных природных ландшафтных заказников «Мыс Фиолент», «Караньский» и «Мыс Айя». В прибрежной зоне этих ООПТ развиваются оползни, обвалы, осыпи, денудация, камнепады, абразия, селевые явления (Ежегодный доклад..., 2018). В частности, площадь обвальнооползневых участков в пределах ландшафтного заказника «Мыс Фиолент» составляет 14,9 га или $40 \%$ территории. Восточнее м. Фиолент обвально-оползневые участки объединены в семь систем, в границах которых растут сообщества краснокнижных можжевельника высокого и фисташки туполистной (Новиков, Каширина, Белоконь, 2014).

С конца прошлого века отмечается рост количества опасных экзогенных геологических процессов на рассматриваемом побережье (рис. 5), что обусловлено, в первую очередь, интенсификацией хозяйственной деятельности в прибрежной зоне. Обобщение и анализ экзогенных событий за период с начала 80-х гг. прошлого века позволил установить, что наибольшую частоту среди них имеют обвалы и камнепады. В течение года обвалы и камнепады происходят, преимущественно, в летний период, оползни - в осенне-зимний. Угроза опасных экзогенных процессов заключается в их способности происходить внезапно и выражаться экстремальными показателями. Наибольшее количество опасных экзогенных событий наблюдается в окрестностях мысов Фиолент и Айя.

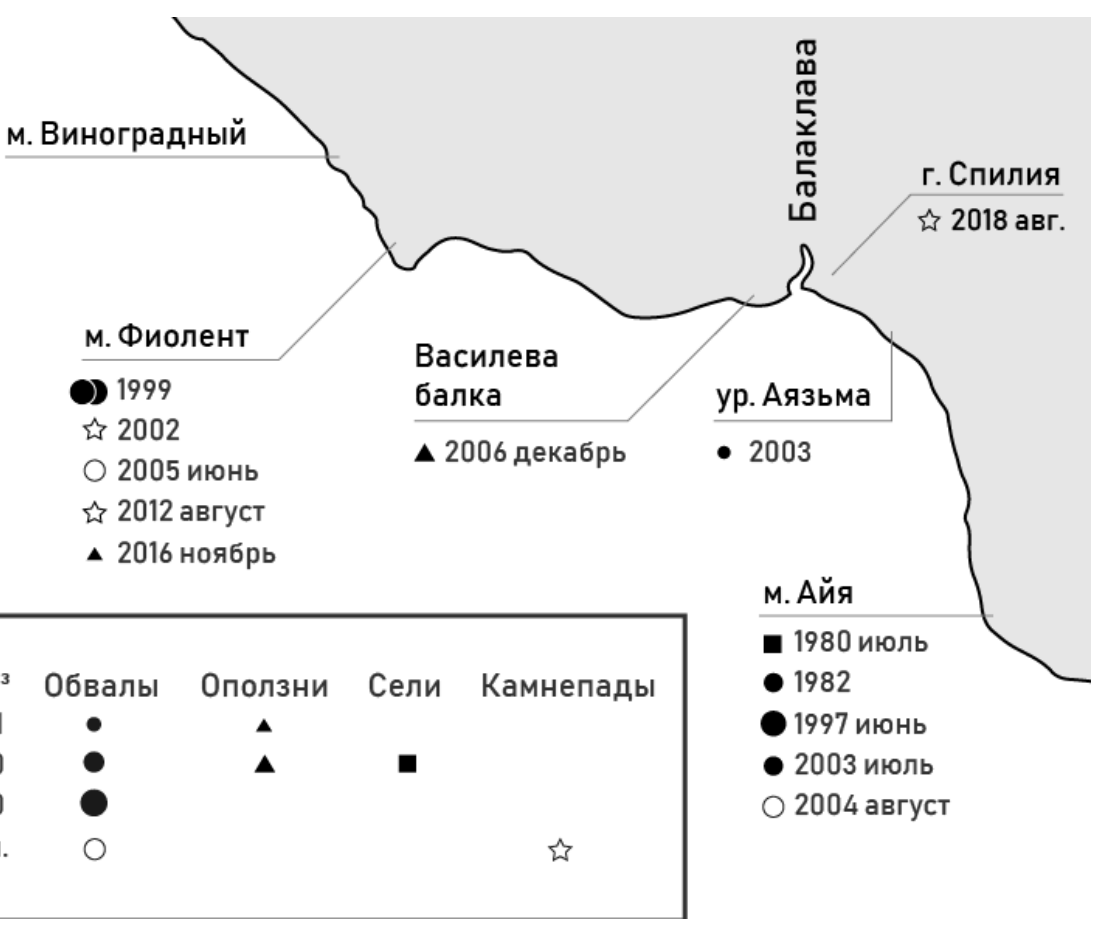

Рис. 5. Основные характеристики и активность опасных экзогенных геологических процессов между м. Виноградный и м. Айя

Для стабилизации берегов необходим контроль всех видов хозяйствования в границах водоохранной зоны моря шириной 500,0 м в соответствии со ст. 65 Водного кодекса РФ. Кроме того, на наиболее опасных участках побережья в районах м. Фиолент, высот Кая-Баш, Караньского плато и м. Айя целесообразно проведение противооползневых, противообвальных, противокамнепадных и противоселевых мероприятий. Например, на оползневых склонах Василевой балки комплекс действий должен включать регулирование поверхностного стока, дренаж обводненных горных пород, создание лесонасаждений. Неустойчивые склоны на обвалоопасных участках у м. Фиолент следует укреплять анкерами, сетками и др. 
Важным является восстановление сети мониторинга экзогенных процессов на побережье в масштабах, существовавших до 2008 г., когда велись аэровизуальные, наземные визуальные, полуинструментальные и инструментальные наблюдения за обвалами и камнепадами у Балаклавы и м. Айя (Доклад «О состоянии...», 2017), а также ее расширение на соседние динамичные участки. Это позволит отслеживать динамику опасных экзогенных процессов и прогнозировать их активизацию.

В связи с ростом травмирования людей на изучаемом побережье остаются актуальными вопросы: создания безопасных зон отдыха (стоянок, пляжей); информирования населения и туристов об участках возможного развития опасных экзогенных процессов; размещения предупредительных, ограничительных и запрещающих знаков и ограждений на местности; распространения среди населения и туристов знаний о необходимости соблюдения техники безопасности во время прогулок и походов. Указанные меры позволят взять под частичный контроль развитие опасных экзогенных геологических процессов в регионе и обеспечить безопасность людей на побережье.

\section{Выводы}

Между м. Виноградный и м. Айя формируются около 15 естественных карманных пляжей максимальной шириной 20,0 м и общей протяженностью 3,5 км. Они имеют, преимущественно, песчано-галечный, гравийно-галечный и галечновалунный гранулометрический состав. В устье Василевой балки из материала отвалов Псилерахского карьера образовался антропогенный пляж шириной 20,0-50,0 м и длиной около 200,0 м. Согласно полевым измерениям авторов и анализу фотоматериалов, средняя скорость роста пляжа Васили за период 2006-2016 гг. составила 1,6-2,5 м/год.

Берега между мысами Виноградный и Айя являются довольно устойчивыми благодаря высокой прочности слагающих их пород. Тем не менее, значительная высота побережья в совокупности с гидрометеорологическими факторами и интенсификацией различных видов хозяйствования создают потенциальные условия для развития здесь опасных и неблагоприятных экзогенных геологических процессов.

На берегах из прочных пород распространены оползни, обвалы, камнепады, осыпи, денудация, сели, карст; из флишей - абразия, оползни, обвалы, осыпи, камнепады, денудация, эрозия и сели. Скорости абразии изменяются от $0-0,005$ м/год на берегах из прочных пород до 0,2-2,5 м/год в делювии флишей. Ведущими факторами активизации прибрежных оползней являются абразия и антропогенная деятельность. Усилению эрозии способствуют антропогенные пожары.

С конца XX в. на рассматриваемом побережье отмечается рост частоты проявления опасных экзогенных геологических процессов, обусловленный, в первую очередь, смещением хозяйственной деятельности к береговой линии. Анализ экзогенных событий за период с начала 80-х гг. прошлого века позволил установить, что наибольшей частотой отличаются обвалы и камнепады. При этом, в годовом цикле развитие обвалов и камнепадов приурочено, главным образом, к летнему периоду, оползней - осенне-зимнему. Наибольшая активность экзогенных процессов отмечается в окрестностях мысов Фиолент и Айя.

Угроза опасных экзогенных геологических процессов заключается в их способности происходить внезапно и выражаться экстремальными показателями. Среди самых крупных экзогенных событий на описываемом побережье выделяются: сель в ущелье урочища Кокия у м. Айя объемом 5,0 тыс. м (июль 1980 г.); обвал в южной части урочища «Затерянный мир» у м. Айя объемом около 90,0 тыс. м ${ }^{3}$ (июнь 1997 г.); обвал у базы отдыха «Каравелла» близ пос. Фиолент объемом 40,0 тыс. м 
(конец 1999 г.); оползень в Василевой балке у Балаклавы объемом около 500,0 тыс. м³ (декабрь 2006 г.).

Для контроля динамики экзогенных процессов и обеспечения безопасности в прибрежной зоне необходимы: восстановление и расширение сети наблюдений за экзогенными процессами; проведение противооползневых, противообвальных, противоселевых и прочих берегозащитных мероприятий; информирование населения и туристов о районах развития опасных экзогенных процессов; размещение предупредительных, ограничительных и запрещающих знаков и ограждений на местности.

\section{Список литературы}

1. Агаркова-Лях И.В. Парагенетические ландшафтные комплексы береговой зоны моря (на примере черноморского побережья Крыма): Дис. ... канд. геогр. наук. Симферополь, 2006. - 205 с.

2. Агаркова-Лях И.В. Развитие экзогенных геологических процессов в береговой зоне Крыма от м. Лукулл до м. Константиновский // Системы контроля окружающей среды. - 2017. - Вып. 10 (30). - С. 58-67.

3. Агаркова-Лях И.В. Современное состояние береговой зоны Севастопольского региона и особенности ее антропогенного преобразования // Культура народов Причерноморья. - 2007. - № 118. - С. 7-13.

4. Агаркова-Лях И.В., Лях А.М. Состояние берегов и экзогенные геологические процессы между м. Константиновский и м. Виноградный на Юго-Западном побережье Крыма // Ученые записки Крымского федерального университета имени В. И. Вернадского. Серия География. Геология. - 2019. - Т. 5 (71). - №2. - С.119131.

5. Агаркова-Лях И.В., Скребеи Г.Н. Ландшафтная карта береговой зоны черноморского побережья Крыма // Ученые записки Таврического Национального Университета им. В.И. Вернадского. Серия «География». - 2007. - Т. 20 (59). № 2. - С. 283-291.

6. Вахрушев Б.А. Районирование карста Крымского полуострова // Спелеологія і карстологія. - 2009. - №3. - С. 39-46.

7. Геолог предсказал обрушение скального массива над пляжем Васили в Севастополе. В. Илларионов. ForPost. Новости Севастополя. 04 августа 2018. [Электронный ресурс]. - Режим доступа: https://sevastopol.su/news/geologpredskazal-obrushenie-skalnogo-massiva-nad-plyazhem-vasili-v-sevastopole (дата обращения: 28.07.2019).

8. Горячкин Ю.Н., Федоров А.П. Оползни Севастопольского региона. Часть 2. Гераклейский по-ов // Экологическая безопасность прибрежной и шельфовой зон моря. - 2018. - Вып. 2. - С. 4-12.

9. Горячкин Ю.Н., Федоров А.П. Оползни Севастопольского региона. Часть 3. Мраморная балка - м. Айя // Экологическая безопасность прибрежной и шельфовой зон моря. - 2019. - Вып.1. - С. 4-15.

10. Доклад «О состоянии и охране окружающей среды на территории Республики Крымм в 2016 году». - Ижевск: ООО «Принт-2», 2017. - 300 с.

11. Долотов B.B., Иванов B.A. Повышение рекреационного потенциала Украины: кадастровая оценка пляжей Крыма. - Севастополь: МГИ НАНУ, 2007. - 194 с.

12. Ежегодный доклад о состоянии и об охране окружающей среды города федерального значения Севастополя за 2015 год [Электронный ресурс]. - Режим доступа: http://ecosev.ru/images/gosdoklad/gosdoklad_Sev_2015.pdf (дата обращения: 28.10.2017). 
13. Ежегодный доклад о состоянии и об охране окружающей среды города Севастополя за 2016 год. Главное управление природных ресурсов и экологии города Севастополя (Севприроднадзор) [Электронный ресурс]. - Режим доступа: http://ecosev.ru/images/gosdoklad/converted_file_eb8f7bea.pdf (дата обращения: 20.07.2019).

14. Ежегодный доклад о состоянии и об охране окружающей среды города Севастополя за 2017 год. Главное управление природных ресурсов и экологии города Севастополя (Севприроднадзор) [Электронный ресурс]. - Режим доступа: http://ecosev.ru/ekologicheskoe-sostoyanie-sevastopolya/doklad-o-sostoyanii-i-obokhrane-okruzhayushchej-sredy-goroda-sevastopolya/2121-prikaz-pr-298-ot-15-06-2018ob-utverzhdenii-ezhegodnogo-doklada-o-sostoyanii-i-ob-okhrane-okruzhayushchejsredy-goroda-sevastopolya-2017-god (дата обращения: 10.08.2019).

15. Ежегодный доклад о состоянии и об охране окружающей среды города Севастополя за 2018 год. Главное управление природных ресурсов и экологии города Севастополя (Севприроднадзор) [Электронный ресурс]. -Режим доступа: http://ecosev.ru/ekologicheskoe-sostoyanie-sevastopolya/doklad-o-sostoyanii-i-obokhrane-okruzhayushchej-sredy-goroda-sevastopolya/2630-ezhegodnyj-doklad-osostoyanii-i-ob-okhrane-okruzhayushchej-sredy-goroda-sevastopolya-za-2018-god (дата обращения: 28.07.2019).

16. Зенкович В.П. Берега Черного и Азовского морей. - М.: Географиздат, 1958а. $374 \mathrm{c}$.

17. Зенкович В.П. Морфология и динамика Советских берегов Черного моря. В 2 т. Т.1. - М.: АН ССCР, 19586. - $216 \mathrm{c}$.

18. Зенкович В.П. Морфология и динамика Советских берегов Черного моря. В 2 т. Т.2. - М.: АН CCCP, 1960. - $216 \mathrm{c}$.

19. Игнатов Е.И., Лукьянова С.А., Соловьева Г.Д. Морские берега Крыма // Геоморфология. - 2016. - №1. - С. 55-63.

20. Игнатов Е.И., Орлова М.С., Санин А.Ю. Береговые морфосистемы Крыма. Севастополь: ЭКОСИ-Гидрофизика, 2014. - 266 с.

21. Изучение оползней Крымской области за 1976-1980 г2. и 1981-1982 г2.: отчет / исполн. И.Ф. Ерыш. - Симферополь: Крымская гидрогеологическая экспедиция 1983. - $100 \mathrm{c}$.

22. Изучение условий развития экзогенных геологических процессов береговой зоны Крымского полуострова: отчет / исполн. Ю.П. Лукьянов. - Симферополь: ГГП «Крымгеология», 1993. - 100 с.

23. Клюкин A.A. Экстремальные проявления неблагоприятных и опасных экзогенных процессов в XX веке в Крыму // Геополитика и экогеодинамика регионов. - 2005. Вып.1. - С. 27-38.

24. Клюкин А.А. Экзогеодинамика Крыма. - Симферополь: Таврия, 2007. - 320 с.

25. Кондратьев С.И., Прусов А.В., Юровский Ю.Г. Наблюдения субмаринной разгрузки подземных вод (Южный берег Крыма) // Морской гидрофизический журнал. - 2010. - № 1. - С.32-45.

26. Корженевский Б.И., Борисенко Л.С., Корженевский И.Б. и др. Литологический контроль гравитационных процессов в Горном Крыму // Бюллетень Московского общества испытателей природы. Отд. Геол. - 1989. - Т. 64. - Вып. 7. - С.45-52.

27. Крупнейший техногенный оползень Крыла. Илларионов В. Онлайн-версия информационной газеты «Слава Севастополя». 14.12.2006 [Электронный ресурс]. -Режим доступа: http://slavasev.ru/2006.12.14/view/14556_krupneyshiy-tehnogennyyopolzen-kryma.html (дата обращения: 12.12.2016). 
28. Лазицкая Н.Ф. Общественно-географическое обоснование развития рекреационного водопользования в г. Севастополь: Автореф. дис. ... канд. геогр. наук. - Симферополь, 2014. - 23 с.

29. Луговой Н.Н. Типизация, районирование и состояние морских берегов Севастополя // Геоморфологи: к юбилейному XXXV Пленуму Геоморфологической комиссии РАН в Симферополе / Под ред. М.Е. Кладовщиковой, Э.А. Лихачевой. Т. 7. - М.: Медиа-Пресс, 2016. - С. 131-142.

30. Мыс Лермонтова с гротом Дианы. Ялта: путеводитель и справочная информация [Электронный pecypc]. - Режим доступа: www.jalita.com (дата обращения: 01.08.2019).

31. Муратов М.В. Руководство по учебной геологической практике в Крыму», Т. II. М.: Недра, 1973. - 192 с.

32. На мысе Фиолент обрушился берег. ForPost. Севастопольский новостной портал. 02.12.2016 [Электронный peсурс]. - Режим доступа: http: //sevastopol.su/news.php?id=92544 (дата обращения: 26.12.2016).

33. На мысе Фиолент произошел очередной обвал земли. С. Степанов. РИА Новый день. 13.06.2005 [Электронный ресурс]. - Режим доступа: https://newdaynews.ru/crimea/29262.html (дата обращения: 26.12.2016).

34. Новиков А.А., Каширина Е.С., Белоконь В.В. Геолого-геоморфологические опасные процессы как факторы угроз для особо охраняемых природных территорий г. Севастополя // Экологическая безопасность прибрежной и шельфовой зон и комплексное использование ресурсов шельфа. - 2014. - Вып. 29. - С. 61-69.

35. Обвал скаль в районе мыса Айя (Украина): гражданину России оторвало руку. ИА REGNUM. 24.08.2004 [Электронный ресурс]. - Режим доступа: https://regnum.ru/news/312486.html (дата обращения: 26.06.2019).

36. Олиферов А.Н. Селевые потоки в Крыму и Карпатах. - Симферополь: Доля, 2005. $175 \mathrm{c}$.

37. Опасные обрушения берегов. Меридиан. Севастополь. 06.04.2013 [Электронный pecypc]. - Режим доступа: https://meridian.in.ua/news/10225.html (дата обращения: 26.06.2019).

38. Орлова М.С. Морские берега Крыма как ресурс рекреации (на примере берегов Западного Крыма): Автореф. дис. ... канд. геогр. наук. - М., 2010. - 26 с

39. Попов М.A. Геоморфологический очерк залива Мегало-Яло и Балаклавской бухты // Экологическая безопасность прибрежной и шельфовой зон и комплексное использование ресурсов шельфа. - 2006. - Вып. 14. - С. 209-214.

40. Попов М.A., Лисицкая Е.В., Поспелова Н.В. Ландшафтное и биологическое разнообразие залива Мегало-Яло (Крым, Черное море) // Экологическая безопасность прибрежной и шельфовой зон и комплексное использование ресурсов шельфа. - 2014. - Вып. 28. - С. 214-219.

41. Прогноз экзогенных геологических прочессов на Черноморском побережье СССР / Под ред. А.И. Шеко, В.С. Круподерова. - М.: Недра, 1979. - 239 с.

42. Разработка методических основ моделирования карста и абразии в Крыму: отчет / Т.3. Текст. Институт минеральных ресурсов. - Симферополь, 1985. - 167 с.

43. Романюк O.C. Пляжи Крыма, их генезис и перспективы практического использования: Автореф. дисс. ... канд. геогр. наук. - Симферополь,1968. - 32 с.

44. Рудько Г.И., Ерыш И.Ф. Оползни и другие геодинамические процессы горноскладчатых областей Украины (Крым, Карпаты). - К.: Задруга, 2006. - 624 с.

45. Сейсмику Крыма никто не отменял, и оползни не покинули Севастополь. В. Илларионов. Крымский новостной портал Іпформер. 03.2016 [Электронный pecypc]. - Режим доступа: http://ruinformer.com (дата обращения: 03.12.2017). 
46. Современное состояние береговой зоны Крыма: атлас-монография / Под ред. Ю.Н. Горячкина. - Севастополь: ЭКОСИ-Гидрофизика, 2015. - 252 с.

47. Составить кадастр надводной части берегов Крыма применительно к масштабу 1:200 000: отчет / Крымская гидрогеологическая экспедиция, Институт минеральных ресурсов; отв. исполн. О.С. Романюк. - Симферополь, 1988.

48. Штенгелов E.C. С какой скоростью отступает обрыв Южного берега Крыма? // Природа. - 1970. - № 8. - С.

49. Шуйский Ю.Д. Процессы и скорости абразии на украинских берегах Черного и Азовского морей // Известия АН СССР. Серия география. - 1974. - №6. - С.108117.

50. Шуйский Ю.Д. Питание обломочным материалом северо-западного и крымского районов шельфа Черного моря // Исследование динамики рельефа морских побережий. - М.: Наука, 1979. - С. 89-97.

51. Шуйский Ю.Д. Проблемы исследования баланса наносов в береговой зоне морей. - Л.: Гидрометеоиздат, 1986. - 240 с.

52. Шуйський Ю.Д. Типи берегів Світового океану. - Одесса: Астропринт, 2000. $480 \mathrm{c}$.

53. Юровский Ю.Г., Байсарович И.М., Щетинин Ю.Т., Кондратьев С.И. Мониторинг субмаринных источников в районе м. Айя // Экологическая безопасность прибрежной и шельфовой зон и комплексное использование ресурсов шельфа. 2000. - Вып. 7. - С. 46-52.

\section{THE STATE OF THE COASTS AND THE DEVELOPMENT OF EXOGENOUS GEOLOGICAL PROCESSES ON SOUTH-WESTERN COASTS OF CRIMEA FROM CAPE VINOGRADNIY TO CAPE AYA Agarkova-Lyakh I.V. ${ }^{1}$, Lyakh A.M. ${ }^{2}$ \\ ${ }^{I}$ Institute of Natural and Technical Systems, Sevastopol, Russian Federation e-mail: iva crimea@mail.ru \\ ${ }^{2}$ A.O. Kovalevsky Institute Marine Biological Researches of RAS, Sevastopol, Russian Federation e-mail:me@antonlyakh.ru}

The history of the study of the southwestern part of the Crimean coast between Cape Vinogradny and cape Aya within the boundaries of Sevastopol is considered. The conditions determining the current state of the coasts, the nature and dynamics of exogenous geological processes are described. Morphometric characteristics of the beaches that are formed here, their genesis, granulometric and material composition are described. The activities of development and spreading of abrasion, landslides, landslips, screes, rockfalls, denudation, mudflows and karst are estimated. On the basis of available data, the quantitative and qualitative characteristics of the most significant exogenous geological events on the coast for the period from the beginning of the 80 s to present are summarized. Actions to improve safety in the coastal zone and control the dynamics of dangerous exogenous processes are proposed.

Keywords: coastal monitoring, beaches, abrasion, landslides, landslips, rockfalls.

Поступила в печать 28.05.2019 2. 